\title{
Analisis Strategi Pemasaran Pada Perguruan Tinggi Swasta Di Kota Mataram (Studi Kasus Pada Sekolah Tinggi IImu Ekonomi AMM)
}

\author{
I Made Suardana ${ }^{1}$; Baiq Desthania Prathama ${ }^{2}$ \\ Sekolah Tinggi IImu Ekonomi AMM \\ imadesuar@yahoo.com, desthania.27@gmail.com
}

\section{ARTICLES \\ INFORMATION}

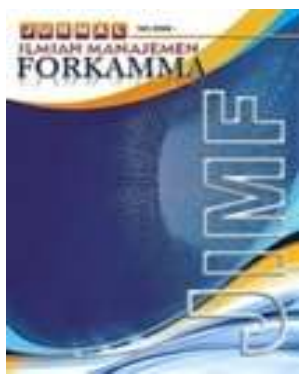

\section{JURNAL ILMIAH MANAJEMEN FORKAMMA}

Vol.4, No.3, Juli 2021

Halaman : $215-228$

(c) LPPM \& FORKAMMA

Prodi Magister Manajemen UNVERSITAS PAMULANG

ISSN (online) : 2599-171X ISSN (print) : : 2598-9545

Keyword :

Lingkungan internal; lingkungan eksternal; SWOT; Strategi

Pemasaran

JEL. classification :

O15,

\section{Contact Author : \\ PRODI \\ MAGISTER MANAJEMEN \& FORKAMMA UNPAM \\ JL.Surya Kencana No.1 \\ Pamulang Tangerang Selatan - Banten \\ Telp. (021) 7412566, Fax (021) 7412491 \\ Email \\ jurnalforkamma.unpam@gmail.com}

ABSTRACT
Penelitian ini bertujuan untuk menganalisis strategi pemasaran pada Perguruan Tinggi Swasta di Kota Mataram". Jenis penelitian ini merupakan penelitian deskriptif. Data dikumpulkan lewat catatan atau dokumen-dokumen (teknik dokumentasi) dan teknik wawancara secara mendalam yang bersumber dari informan. Data dianalisis dengan menggunakan analisis kuantitatif : (SWOT, EFAS - IFAS serta grand strategy) dan analisis kualitatif.

Hasil penelitian menunjukkan bahwa strategi level korporasi yang diterapkan oleh STIE AMM berdasarkan analisis yang telah dilakukan adalah strategi diversifikasi, dengan memperbanyak produk pelayanan pendidikan yang tidak berbeda dengan produk utamanya. Strategi level fungsional untuk mendukung diversifikasi yaitu: strategi positioning product, diversifikasi produk, strategi penetration pricing, promosi yang dapat membentuk image konsumen potensial dan bersifat periodik, produk pelayanan pendidikan sedekat mungkin dengan konsumen, dan strategi harga yang dapat bersaing serta pemberian potongan bagi mahasiswa berprestasi, serta personal traits yang aspiratif.

This study aims to analyze marketing strategies at private universities in the city of Mataram" (Case Study at AMM College of Economics). This type of research is descriptive research. Data were collected by looking at notes or documents related to the purpose of this research (documentation technique) and in-depth interview techniques sourced from key informants who were deemed to have in-depth knowledge of the problems of this research. The data that was collected were analyzed using quantitative analysis (SWOT, EFAS - IFAS and grand strategy) and qualitative analysis.

The results show that the corporate level strategy implemented by STIE AMM based on the analysis that has been done is a diversification strategy, by multiplying educational service products that are not different from the main product. Functional level strategies to support diversification, namely: product positioning strategy, product diversification, penetration pricing strategy, promotions that can shape the image of potential consumers and are periodic, educational service products as close as possible to consumers, and competitive pricing strategies as well as giving discounts for outstanding students. , as well as aspirational personal traits. 


\section{A. PENDAHULUAN}

Tahun 2020 merupakan tahun terberat bagi semua negara di dunia, dimana wabah Corona atau Covid 19 melemahkan hampir seluruh negara termasuk Indonesia. Pembatasan aktivitas akan menyebabkan adanya dampak yang dapat mempengaruhi laju pertumbuhan ekonomi Indonesia. Hal ini dapat dirasakan oleh masyarakat Indonesia dari semua lapisan termasuk di bidang pendidikan. Pendidikan merupakan kebutuhan hidup manusia untuk meningkatkan penguasaannya atas ilmu pengetahuan sebagai modal memecahkan berbagai masalah kehidupan. Pemerintah juga memberikan perhatian terhadap pendidikan guna meningkatkan sumber daya manusia yang merupakan faktor penting untuk melaksanakan pembangunan.

Pemerintah dalam geraknya meningkatkan pelayanan pendidikan pada masyarakat masih jauh dari mencukupi, baik dilihat dari kuantitas maupun kualitasnya. Hal tersebut menyebabkan banyaknya pihak swasta yang bergerak dalam penyelenggaraan pendidikan. Kondisi tersebut kemudian menyebabkan persaingan dalam pelayanan pendidikan (pemerintah dan swasta) menjadi lebih kompetitif. Masing-masing pelaku pelayanan pendidikan mengharapkan mendapatkan mahasiswa baru (input) yang optimal. Hanya melalui perolehan input (masukan) yang mencukupi menyebabkan pelaksanaan pelayanan pendidikan dapat bertahan atau tumbuh menjadi lembaga pendidikan yang besar.

Dewasa ini, konsep bisnis sangat perlu diterapkan dalam pengadaan pelayanan pendidikan, sehingga dapat dinyatakan bahwa pendidikan telah masuk sebagai salah satu bentuk bisnis. Prinsip bisnis bukan berarti mencari laba semaksimal mungkin, karena prinsip tersebut telah tidak terpakai. Prinsip yang perlu diterapkan ditujukan untuk mencapai kepuasan yang semakin meningkat serta kesejahteraan konsumen tersebut dapat dicapai dalam jangka panjang.

Lembaga nirlaba termasuk dunia pendidikan sangat perlu menerapkan konsep bisnis yang tepat, sehingga dapat bertahan dalam usaha yang dilakukan. Dapat juga ditegaskan, bahwa lembaga nirlaba memerlukan cash in flow yang lebih tinggi dari cash out flow, sehingga dapat memberikan pelayanan yang memuaskan pada konsumen sasarannya. Konsep bisnis perlu diterapkan dalam bisnis pendidikan, di mana melalui kepuasan konsumen (mahasiswa) dan memperhatikan kesejahteraan mahasiswa merupakan syarat sukses dari bisnis pendidikan yang dilakukan. Kepuasan mahasiswa berhubungan dengan terwujudnya keinginan atau harapannya pada saat memilih perguruan tinggi bersangkutan. Berhubungan dengan kesejahteraan mahasiswa, perguruan tinggi bersangkutan memberikan pendidikan yang sesuai dengan pasar kerja yang ada, selanjutnya dapat digunakan untuk mendapatkan kesempatan kerja (Risdwiyanto \& Dharmmesta, 2001)

Pelaku bisnis pendidikan harus memperhatikan janji yang akan diberikan kepada calon mahasiswanya, sebab jika ada mahasiswa yang merasa janji perguruan tinggi bersangkutan tidak terpenuhi, maka akan memberikan dampak pada ketidakpuasan mahasiswa yang bersangkutan. Ketidakpuasan dapat berdampak pada tuntutan atau keluhan, bahkan tuntutannya dapat melalui jalur hukum atau menampilkannya di media massa. Apabila hal tersebut terjadi, maka sangat merugikan nama baik perguruan tinggi bersangkutan.

Dalam rangka memenangkan persaingan, maka hal yang dilakukan oleh pelaku bisnis pendidikan adalah menerapkan strategi pemasaran yang efektif. Strategi pemasaran menunjukkan usaha untuk menyesuaikan kondisi internal perusahaan dan lingkungannya. Terkait dengan hal di atas, maka pihak pelaku bisnis pendidikan harus dapat menerapkan kebijakan bauran produk, harga, promosi dan distribusi yang tepat sebagai hasil analisis dari kondisi internal dan eksternalnya. Analisis kondisi internal dan eksternal harus dilakukan secara periodik, karena kedua lingkungan tersebut mengalami 
perubahan-perubahan yang menuntut adanya perubahan kebijakan bauran pemasaran (Tjiptono, 2008)

Dalam bidang pendidikan, bukan hanya bauran produk, harga, promosi dan distribusi menjadi komponen dari marketing mix. Oleh (Alma, 2018) dimasukkan juga unsur personal traits. Personal traits terdiri atas komponen karyawan (dosen dan tenaga administrasi), pimpinan dan yayasan dalam pemasaran pendidikan yang diterapkan. Dalam strategi pemasaran telah dijelaskan bahwa langkah pertama yang dilakukan adalah melakukan analisis lingkungan internal dan eksternal badan usaha. Analisis lingkungan internal dilakukan untuk menemukan kelemahan dan keunggulan berbagai aspek internal. Adapun analisis lingkungan eksternal dilakukan untuk menemukan peluang dan hambatan yang muncul. Melalui perpaduan dua aspek tersebut diterapkan berbagai bauran pemasaran untuk mendukung strategi yang tepat.

Tentunya, seluruh PTS di Kota Mataram sangat perlu melakukan kajian yang mendalam mengenai permasalahan yang dihadapi. PTS tidak dapat dijalankan hanya dengan mengikuti waktu, karena faktor eksternal terus mengalami perubahan. Faktor eksternal yang berubah berupa munculnya pesaing-pesaing baru, baik dari PTS ataupun Perguruan Tinggi Negeri (PTN). PTN utama di Kota Mataram, yaitu Universitas Mataram pada setiap fakultas membuat program ekstension, bahkan program diploma. Universitas Islam Negeri (UIN) Mataram dan Sekolah Tinggi Agama Hindu Negeri "Gede Pudja" (STAHN "Gede Pudja") Mataram juga merupakan pesaing, karena dalam perkembangannya tidak hanya membuka program mengenai Islam dan Hindu saja, tetapi pendidikan ekonomi, biologi dan berbagai ilmu pengetahuan alam lainnya. Pada kasus di atas pasar potensial untuk setiap PTS juga menjadi pasar program baru yang dibuat oleh Unram dan UIN, serta STAHN "Gede Pudja". Kondisi ini mengharuskan PTS di Kota Mataram melakukan perbaikan, jika menginginkan perolehan mahasiswa yang memadai.

Fenomena permasalahan yang diuraikan di atas perlu untuk dilakukan kajian yang mendalam dalam bisnis pendidikan, khususnya yang dilakukan oleh pihak swasta. Kajian yang dilakukan adalah mencoba untuk menemukan strategi pemasaran yang dapat diterapkan oleh PTS di Kota Mataram, khususnya Sekolah Tinggi IImu Ekonomi AMM (STIE AMM) Mataram dalam menjalankan bisnisnya, selanjutnya dilakukan analisis atas strategi pemasaran bersangkutan. Analisis tersebut akhirnya akan memberikan temuan tepat atau tidaknya strategi yang dilakukan dan memberikan solusi strategi yang efektif.

Penelitian ini bertujuan untuk mengkaji dan menganalisis mengenai kondisi internal dan eksternal pada STIE AMM. Di sisi lain, penelitian ini bermaksud untuk melakukan kajian efektvitas strategi pemasaran yang diterapkan oleh STIE AMM. Kontribusi dari penelitian ini dilihat dari sudut pengambil kebijakan adalah adalah sebagai pedoman strategi pemasaran pada masing-masing PTS yang ada di Kota Mataram, khususnya STIE AMM. Di sisi lain, sebagai salah satu masukan bagi L2Dikti Wilayah 8 Denpasar dalam upaya bagaimana mengembangkan dan memberdayakan PTS-PTS yang ada di Kota Mataram khususnya di STIE AMM Mataram.

\section{B. KAJIAN LITERATUR}

\section{Konsep Pemasaran}

Konsep pemasaran sebagai pedoman dalam menjalankan bisnis, termasuk dalam dunia pendidikan. Pada awalnya, alat pemuas kebutuhan sangat terbatas kuantitas dan keberagamannya, sehingga orientasi yang muncul pada tahap tersebut adalah orientasi produksi. Hal utama yang menjadi pemikiran pada periode tersebut adalah bagaimana menghasilkan suatu produk, termasuk dalam dunia pendidikan. Pada awalnya pelaku bisnis pendidikan hanya memperhatikan upaya untuk menghasilkan pelayanan pendidikan. Akan tetapi, sejalan dengan permintaan yang meningkat mengenai pelayanan pendidikan, maka jumlah penyelenggara pendidikan mengalami peningkatan. Dengan adanya berbagai alternative untuk memenuhi kebutuhannya, maka konsumen potensial 
pendidikan perlu melakukan pemilihan alternatif perguruan tinggi yang akan dimasuki untuk memenuhi kebutuhan pendidikannya. Salah satu hal penting yang menjadi perhatian konsumen potensial selanjutnya adalah perguruan tinggi yang dapat memenuhi keinginan atau harapannya (Risdwiyanto \& Dharmmesta, 2001)

Hal penting yang menjadi perhatian konsep pemasaran adalah kepuasan konsumen, di mana hanya melalui kepuasan konsumen perusahaan dapat mewujudkan tujuannya. Pentingnya kepuasan konsumen sebagai syarat suksesnya suatu bisnis, maka banyak kajian mengenai upaya untuk mewujudkan kepuasan konsumen. Di antara konsep yang melakukan kajian mengenai pentingnya kepuasan konsumen dan upaya untuk mewujudkannya adalah pendekatan TQS (Total Quality Service) dan rantai laba pelayanan. Komponen yang terdapat di dalam konsep TQS adalah sumber daya manusia, strategi dan konsumen (Tjiptono \& Chandra, 2011). Dalam TQS semua strategi dan sumber daya manusia diarahkan pada usaha pemenuhan kebutuhan dan keinginan konsumen, yang selanjutnya diharapkan dapat menciptakan kepuasan konsumen. Perusahaan hanya akan dapat membentuk kepuasan konsumen hanya melalui pembentukan kepuasan karyawan. Dengan terpenuhinya kepuasan karyawan, maka karyawan akan dapat menggunakan seluruh potensinya dalam bekerja, selanjutnya akan diperoleh produktivitas karyawan yang tinggi.

Konsep di atas sangat perlu diperhatikan bagi pelaku penghasil pelayanan pendidikan. Pelayanan yang optimal hanya akan dapat diberikan, jika karyawan atau konsumen internal terlebih dahulu dipuaskan. Sebagaimana disampaikan oleh (Manurung et al., 2016) bahwa kemampuan perusahaan dalam mengembangkan keahlian para karyawannya dengan baik akan menjadikan perusahaan tersebut unggul dan penerapan strategi yang berbasis sumber daya manusia akan sulit untuk diikuti oleh para pesaingnya. Karyawan dalam perguruan tinggi berupa dosen dan tenaga administrasi akademik sangat perlu dipuaskan terlebih dahulu, sehingga potensi yang dimiliki dikembangkan sedemikian rupa, di mana akhirnya akan berwujud pada pemberian pelayanan yang memuaskan pada mahasiswa, baik mahasiswa efektif ataupun mahasiswa potensial.

\section{Strategi Pemasaran}

Strategi yang diterapkan oleh perusahaan pada dasarnya mengacu pada upaya untuk mewujudkan tujuan perusahaan. Tujuan perusahaan secara umum adalah laba, dan keberlangsungan hidup dari perusahaan. Laba yang diharapkan tentunya adalah laba yang optimal, penjualan yang meningkat dalam konteks penguasaan pasar yang tinggi dan keberlangsungan hidup perusahaan.

Mengacu pada berbagai elemen strategi pemasaran pada dasarnya berbicara mengenai penetapan bauran pemasaran. Bauran pemasaran merupakan "seperangkat alat pemasaran yang digunakan perusahaan untuk mencapai tujuannya dalam pasar sasaran" (Kotler \& Armstrong, 2012). Bauran Pemasaan dimaksud meliputi 4Ps (product, price, place, promotion) yang harus dapat diterapkan dengan cara yang tepat.

Konsep berpikir tersebut juga harus dilakukan oleh pelaku bisnis pendidikan, di mana yang diperhatikan tidak hanya terdiri atas 4Ps, tetapi sesuai dengan komponen yang ada dalam dunia pendidikan menurut (Alma, 2018) juga memasukkan personal traits, terdiri atas komponen personil, pimpinan dan yayasan dalam pemasaran pendidikan.

\section{Lingkungan Internal dan Eksternal}

Setiap bisnis, termasuk bisnis pendidikan mengahadapi persaingan yang kompetitif. Untuk itu, pihak pengambil keputusan di dalam lembaga harus melakukan kajian yang mendalam sebelum ditetapkan keputusan tertentu. Kajian tersebut pada dasarnya adalah kajian terhadap lingkungan internal dan eksternal perusahaan. Hal ini sesuai dengan 
makna dan strategi pemasaran, di mana bauran pemasaran yang ditetapkan tergantung pada hasil analisis kedua lingkungan tersebut.

Tujuan dari analisis lingkungan eksternal pada dasarnya adalah menemukan lingkungan muncul sebagai peluang. Setiap peluang harus dimanfatkan semaksimal mungkin, karena perusahaan mempunyai pesaing. Alternatif lain yang muncul dalam lingkungan eksternal adalah ancaman. Ancaman dalam lingkungan pemasaran merupakan "tantangan akibat kecenderungan atau perkembangan yang kurang menguntungkan. Faktor lingkungan perusahaan yang penting juga dianalisis adalah lingkungan internal. Faktor lingkungan internal, berarti melakukan kajian atas kondisi di dalam perusahaan atau lembaga itu sendiri, di mana memunculkan dua kemungkinan, yaitu keunggulan dan kelemahan.

\section{Kilasan SWOT}

Kajian dalam penelitian ini adalah mengenai strategi pemasaran, selanjutnya digunakan bantuan analisis SWOT untuk mengidentifikasi strategi yang akan dirumuskan. Hal ini senada dengan pengertian yang diberikan oleh (Rangkuti, 2014) mengenai analisis SWOT sebagai "identifikasi berbagai faktor secara sistematis untuk merumuskan strategi perusahaan".

Aktualisasi berbagai strategi tersebut dapat dilakukan pada strategi level fungsional dengan menerapkan kebijakan bauran pemasaran yang tepat. Analisis pada tahap pembentukan matrik SWOT masih belum spesifik, karena muncul beberapa strategi dari berbagai kombinasi kondisi lingkungan internal dan kondisi ekternal. Berhubungan dengan hal tersebut, maka perlu dilakukan analisis lanjutan untuk menemukan satu strategi level korporat (Kotler, 2012)

Analisis yang dapat menjawab permasalahan tersebut adalah analisis grand strategy yang merupakan penerapan lebih lanjut dari analisis SWOT. Tahap pertama dari analisis tersebut adalah pembentukan matriks SPACE (Rangkuty, 2014). Matriks SPACE merupakan matrik yang berisikan identifikasi keunggulan, kelemahan, peluang dan hambatan dari perusahaan yang dianalisis, lengkap dengan skor yang diberikan.

\section{B. METODOLOGI PENELITIAN}

Jenis penelitian dalam penelitian ini adalah penelitian deskriptif. Dalam penelitian ini dilakukan deskripsi mengenai posisi dari pelaku bisnis pendidikan dalam industrinya, kondisi internal dan eksternalnya dan gambaran mengenai strategi bauran pemasaran yang ditetapkan. Teknik pengumpulan data yang digunakan adalah wawancara yaitu teknik pengumpulan data dengan melakukan tanya jawab dengan responden dan teknik dokumentasi yaitu teknik pengumpulan data dengan cara melakukan pencatatan atas dokumen yang dimiliki oleh objek penelitian. Data yang dikumpulkan berupa kondisi karyawan, kondisi pemasaran, promosi dan keuangan yang dimiliki. Sedangkan alat pengumpulan data yang digunakan adalah angket. Angket dalam penelitian ini digunakan untuk mendapatkan data mengenai kondisi internal perusahaan dan eskternal perusahaan (khususnya mengenai konsumen atau mahasiswanya) (Cooper \& Emory, 1996)

Analisis data yang digunakan dalam penelitian ini adalah Analisis SWOT, yaitu analisis yang memberikan gambaran mengenai kekuatan, kelemahan, peluang dan ancaman dari STIE AMM. Dengan analisis SWOT diharapkan dapat menterjemahkan dan mengidentifikasi aspek internal dan eksternal sebagai berikut :

a. Analisis lingkungan internal, lebih memfokuskan pada identifikasi kekuatan dan kelemahan. Lingkungan internal yang akan dianalisis dalam hal ini adalah kondisi sumber daya manusia, kondisi finansial, kondisi proses belajar mengajar sebagai bentuk proses produksi, kondisi pemasaran, administrasi dan akuntansi. 
b. Analisis lingkungan eksternal; analisis lingkungan eksternal, berarti menggali dan mengidentifikasi semua peluang yang berkembang dan ancaman dari para pesaing dan calon pesaing. Lingkungan eksternal meliputi eksternal makro dan lingkungan eksternal mikro. Eksternal makro, seperti data nilai tukar, inflasi, suku bunga, pertumbuhan ekonomi, kesempatan kerja, sosial, budaya, religi dan pemerintah. Sementara itu, pada eksternal mikro berupa pesaing dan hubungan dengan sumber input dan penyedia lapangan pekerjaan.

Efektivitas strategi pemasaran dilihat dari pengaturan bauran produk, bauran promosi, bauran harga, bauran distribusi dan personal traits terkait dengan posisi STIE AMM dalam diagram SWOT. Penyusunan diagram SWOT atau diagram grand strategy di atas dilakukan melalui penyusunan matriks SPACE. Matrik SPACE berisikan identifikasi faktor internal dan eksternal berupa keunggulan dan kelemahan serta peluang dan hambatan, di mana masing-masing telah diberikan penskoran sesuai dengan kriterianya. Melalui selisih rata-rata skor dari keunggulan dengan kelemahan dan selisih antara ratarata skor peluang dengan hambatan dapat diketahui kondisi umum dari faktor internal dan eksternal. Melalui analisis ini baru dapat diketahui posisi perusahaan pada setiap kuadran dari diagram SWOT bersangkutan (Tjiptono \& Chandra, 2012)

\section{HASIL DAN PEMBAHASAN}

\section{Hasil Penelitian}

Uraian mengenai kondisi internal dan eksternal STIE AMM dilakukan identifikasi masing-masing aspek. Identifikasi tersebut untuk menentukan faktor internal muncul sebagai kekuatan atau kelemahan dan faktor eksternal muncul sebagai peluang atau hambatan. Uraian berbagai aspek intern SITE AMM telah dilakukan yang dapat memberikan gambaran mengenai kondisinya. Aspek karyawan dinilai dari unsur kuantitas, kualitas, kerajinan dan tingkat perputarannya. Seluruhnya mendapatkan penilaian baik, karena memenuhi ketentuan yang ada.

Dilihat dari segi kuantitas, bahwa harus terdapat 6 orang dosen tetap sesuai dengan bidang pendidikannya dan jumlah dosen memenuhi ketentuan 1:40 (1 dosen berbanding 40 mahasiswa). Karyawan, baik karyawan adminsitrasi ataupun dosen mempunyai tingkat kehadiran yang mendekati 95,00 persen, jadi dapat diberikan kriteria baik. Dosen dan karyawan AMM juga mempunyai loyalitas yang tinggi, di mana dapat dilihat dari tingkat perputarannya (keluar dan masuk). Karyawan tetap (dosen dan administrasi) mempunyai kisaran 0,04 persen yang dapat dikriteriakan rendah.

Mengacu pada pemberian skoring pada masing-masing unsur yang terdapat dalam aspek karyawan, maka dapat dinyatakan bahwa secara umum kondisi karyawan dalam kondisi yang baik. Berdasarkan hal tersebut dapat dikriteriakan sebagai keunggulan. Total skor yang diperoleh sebesar 16 dari 20 skor maksimal, sehingga persentase total skor tersebut terhadap skor maksimal sebesar 80,00 persen.

Untuk lebih jelasnya kriteria masing-masing aspek internal dan eksternal STIE AMM dapat ditampilkan rekapitulasi pada Tabel 2 dan 3

Tabel 2. Kriteria Aspek Internal STIE AMM Tahun 2020.

\begin{tabular}{clcl}
\hline No. & Aspek Internal & Persentase Skor & Kriteria \\
\hline 1. & Karyawan & 80,00 & Keunggulan \\
\hline 2. & Finansial & 65,00 & Keunggulan \\
\hline 3. & Produksi & 72,00 & Keunggulan \\
\hline 4 & Pemasaran & 68,00 & Keunggulan \\
\hline
\end{tabular}

Sumber : Data primer diolah

Keterangan : Pemberian kriteria keunggulan, jika persentase skor di atas 50,00 persen 
Berdasarkan hasil analisis yang ditampilkan pada Tabel 2 diketahui bahwa secara umum aspek internal yang dimiliki oleh STIE AMM muncul sebagai keunggulan. Artinya dapat digunakan sebagai upaya untuk memanfaatkan peluang yang ada dan meminimalkan kerugian akibat dari hambatan yang muncul dari faktor eksternal.

Aspek finansial muncul sebagai keunggulan secara umum, karena dilihat dari kecukupan modal kerja, likuiditas dan solvabilitas tergolong sangat baik. Kriteria sangat tidak baik terjadi pada pencapaian rasio aktivitas. Modal kerja yang dimiliki oleh STIE AMM selalu dapat mencukupi biaya operasionalnya. Kondisi finansial juga perlu dilihat dari likuiditas dan solvabilitasnya, di mana pencapaian kedua rasio tersebut tergolong cukup baik. Kriteria yang diberikan untuk likuiditas dan solvabilitasnya adalah likuid dan solvabel. Artinya, pihak STIE AMM dapat menjamin hutang lancarnya akan dapat tepat terbayar pada saat jatuh tempo, begitu juga dengan pembayaran total hutangnya dengan total aktiva yang dimilikinya.

Kondisi di atas tidak terjadi pada pencapaian rasio aktivitas. Aktivitas STIE AMM tergolong rendah, yang menunjukkan perolehan penerimaan tidak sesuai dengan total nilai aktiva. Adanya unsur dalam aspek finansial yang mempunyai kriteria baik dan tidak baik tidak menyebabkan kondisi umumnya aspek finansialnya mempunyai kriteria lemah, tetapi sebaliknya mempunyai kriteria keunggulan. Hal tersebut terlihat dari pencapaian persentase skor aktual dengan skor maksimal lebih dari 50,00 persen, tepatnya sebesar 65,00 persen.

Kriteria umum aspek finansial di atas juga terjadi pada aspek produksi, yaitu muncul sebagai keunggulan. Penilaian umum tersebut berdasarkan persentase antara total skor aktual dengan skor maksimal sebesar 72,00 persen, lebih dari 50,00 persen. Untuk lebih rincinya penilaian aspek produksi tersebut perlu diuraikan penilaian pada masing-masing unsurnya.

Unsur output dengan kuantitas yang cukup besar dapat terserap dalam lapangan pekerjaan dengan persentase yang cukup tinggi. Pihak pengelola mempunyai program khusus penanganan output, setidaknya memberikan informasi peluang kerja, melakukan hubungan baik dengan pihak penyedia lapangan pekerjaan. Untuk unsur output diberikan penilaian baik (skor 4), penilaian tersebut sama untuk penggunaan peralatan dalam proses belajar mengajar. Akan tetapi, terkait dengan administrasi diberikan penilaian tidak baik (skor 1). Penilaian tersebut dengan pertimbangan, bahwa pelayanan administrasi yang diberikan hanya pada kelas pagi, sementara pada kelas sore dan malam hari pelayanan administrasi sangat minimal.

Dalam pelajaran tertentu, pihak pengelola menggunakan teknologi tertentu, tetapi sebatas pada penggunaan komputer dan laboratorium bahasa Inggris. Teknologi tersebut merupakan teknologi umum yang telah biasa digunakan untuk pelajaran bersangkutan. Adanya hal tersebut, maka diberikan penilaian cukup baik (skor 3). Proses belajar mengajar yang berjalan di STIE AMM tergolong lancar, karena dimiliki fasilitas yang mendukung. Apabila penerangan dari PLN mengalami gangguan, pihak manajemen telah menyediakan fasilitas tersendiri, sehingga proses belajar mengajar tidak terganggu. Adanya hal ini, maka diberikan penilaian baik (skor 4).

Program penanganan output oleh pengelola perlu mendapatkan perbaikan. Pada periode terakhir hanya dilakukan pelayanan informasi lapangan kerja dan membina hubungan baik dengan pihak penyedia lapangan pekerjaan. Dalam aktualisasinya tidak lagi ditemukan pihak penyedia lapangan pekerjaan mencari karyawan di STIE AMM. Adanya kondisi ini, maka penanganan output oleh pengelola diberikan kriteria cukup baik (skor 3).

Aspek penting dalam suatu lembaga yang perlu mendapatkan kajian mendalam adalah aspek pemasaran. Aspek pemasaran dalam kajian ini dilihat dari berbagai bauran pemasaran, personal traits dan good will yang dilihat dari tingkat kepuasan mahasiswa. Aspek pemasaran secara keseluruhan mendapatkan penilaian sebagai keunggulan. Persentase total skor yang diperoleh dari penilaian masing-masing unsurnya sebesar 
68,00 persen dari skor maksimal. Unsur lain dari aspek pemasaran adalah kebijakan bauran pemasaran yang dirumuskan selama ini oleh pengelola. STIE AMM mempunyai upaya yang baik dalam peningkatan kualitas output, baik dilihat dari segi fisik sampai proses belajar mengajarnya. Untuk item tersebut diberikan penilaian baik (skor 4).

Produk yang dihasilkan oleh suatu badan, termasuk pelayanan pendidikan oleh STIE AMM harus dikomunikasikan dengan pasar potensial. Pihak manejemen melakukannya melalui media brosur, elektronik, kunjungan dan media massa. Berbagai media tersebut dilihat dari intensitas dan waktu pelaksanaannya relatif terbatas, sehingga diberikan penilaian cukup baik (skor 3). Penilaian tersebut juga diberikan untuk penerapan bauran harga, di mana tidak dilakukan upaya penerapan bauran harga dengan baik. Kebijakan yang diterapkan hanya terkait dengan harga dasar, tidak dilakukan discount atau sejenisnya bagi input berkualitas. Adanya hal tersebut, maka penilaiannya secara umum diberikan kriteria cukup baik (masing-masing dengan skor 3 ).

Pelayanan pendidikan yang diberikan harus dapat diperoleh dengan mudah. Berhubungan dengan hal tersebut adalah penerapan bauran distribusinya, di mana diberikan kriteria baik (skor 4) untuk aspek tersebut, STIE AMM mempunyai lokasi yang strategis, dilihat dari berbagai hal, sehingga mahasiswa dapat dengan mudah mendapatkan pelayanan pendidikan yang ditawarkan. Administrasi merupakan faktor penting, di mana unsur yang dinilai adalah struktur organisasi, hubungan dengan yayasan dan pencatatan pengeluaran dan masukan. Struktur organisasi dan implikasinya mendapatkan penilaian baik (skor 4), hubungan dengan yayasan mendapatkan penilaian sangat baik (skor 5) dan pencatatan dan pengeluaran, sehingga terhindar dari kecurangan dapat diatasi. Untuk hal terakhir tersebut diberikan kriteria baik (skor 4). Dalam pelayanan pendidikan aspek bauran pemasaran perlu ditambah dengan personal traits. Personal traits yang mendapatkan kajian dalam penelitian ini adalah ciri pribadi dari Ketua, para Pembantu Ketua dan karyawan yayasan yang berhubungan dengan STIE AMM. Dilihat dari tingkat pendidikan, kerajinan dan pengambilan keputusan berbagai pihak tersebut mendapatkan penilaian dengan kriteria baik (skor 4).

Selanjutnya yang perlu mendapatkan kajian dari aspek pemasaran adalah goodwiil yang dibina selama ini. Goodwill atau nama baik sangat perlu dibina, karena terkait dengan keterjaminan jumlah input dari informasi positif mahasiswa efektif kepada mahasiswa potensial dan pihak lainnya. Untuk memberikan penilaian pada unsur nama baik tersebut dilakukan melalui analisis kepuasan konsumen. Secara umum diperoleh hasil kajian bahwa mahasiswa efektif mempunyai kriteria kepuasan yang pada umumnya sangat puas dan puas, walaupun masih ada mahasiswa yang perlu ditingkatkan pemenuhan harapannya. Adanya penilaian tersebut mendapatkan kriteria baik (skor 4).

Tabel 3. Kriteria Aspek Eskternal STIE AMM Tahun 2020.

\begin{tabular}{cllc}
\hline No. & \multicolumn{1}{c}{ Aspek Eksternal } & Persentase Skor & Kriteria \\
\hline 1. & Makro ekonomi (ekonomi nasional) & 68,75 & Peluang \\
\hline 2. & Ekonomi regional & 66,67 & Peluang \\
\hline 3. & Pemerintah & 80,00 & Peluang \\
\hline 4. & Sumber input dan penyerap output & 40,00 & Hambatan \\
\hline 5 & Pesaing & 20,00 & Hambatan \\
\hline 6 & Sosial, budaya dan religi & 100,00 & Peluang \\
\hline
\end{tabular}

Sumber : Data primer diolah

Keterangan : Pemberian kriteria peluang, jika persentase skor di atas 50,00 persen

Makro ekonomi Indonesia menunjukkan adanya arah perbaikan dengan berbagai kebijakan pemerintah yang mendukung sektor ekonomi, walaupun masih dalam masa wabah Pandemi Covid 19. Dinyatakan ada perbaikan, karena indikator ekonomi makro yang dijadikan sebagai indikator oleh Bank Indonesia perlahan mengalami perubahan 
kearah perbaikan. Pemerintah secara umum mempunyai perhatian terhadap pendidikan, secara umum terlihat dalam pembukaan UUD 1945, bahwa tujuan negara adalah mencerdasakan kehidupan masyarakat. Secara praktiknya, ditetapkan berbagai peraturan pemerintah yang memberikan dukungan atas pelaksanaan perguruan tinggi sebagai pemberi pelayanan pendidikan.

Pengelola STIE AMM sangat perlu memperhatikan faktor eksternal, sebagai dasar untuk merumuskan strategi. Salah satu faktor eksternalnya adalah sumber input (sumber mahasiswa, yaitu SMA dan sederajat) dan pihak perusahaan atau badan yang akan menyerap output yang dihasilkan. Hubungan dengan sumber input mendapatkan penilaian muncul sebagai penghambat. Penilaian untuk pesaing, di mana dilihat dari kuantitas dan kualitasnya tergolong sebagai penghambat. Adanya penilaian tersebut, maka persentase skor untuk aspek pesaing sebesar 20,00 persen dengan kriteria muncul sebagai hambatan.

Aspek penting yang perlu mendapatkan penilaian adalah sosial, budaya dan religi. Kondisi sosial, budaya dan religi yang ada di NTB tidak ada yang menjadi penghambat. Kriteria yang diberikan adalah sangat muncul sebagai peluang, sehingga persentasenya atas skor maksimal sebesar 100,00 persen (sangat berpeluang).

Mengacu pada penilaian pada aspek internal dan eksternal STIE AMM, maka dapat dirumuskan matriks SWOT, lihat Tabel 4.

Tabel 4. Matrik SWOT AMM Tahun 2020.

\begin{tabular}{|c|c|c|}
\hline EFAS & 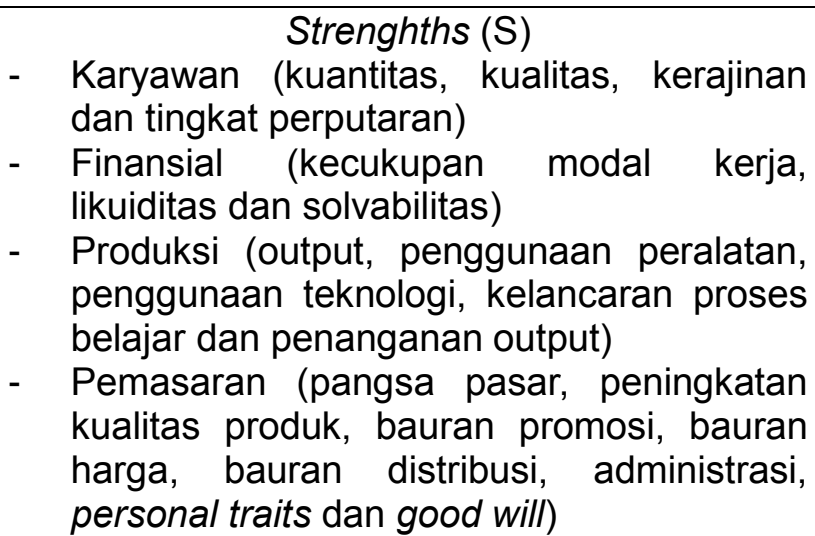 & $\begin{array}{l}\text { Weaknesses (W) } \\
\text { - } \text { Finansial } \\
\text { (aktivitas dan } \\
\text { profitabilitas) } \\
\text { - } \text { Bauran produk } \\
\text { (diversifikasi } \\
\text { produk) }\end{array}$ \\
\hline $\begin{array}{l}\text { Opportunities (O) } \\
- \text { Makro ekonomi } \\
\text { - } \text { Ekonomi } \\
\text { regional } \\
\text { - } \\
\text { Pemerintah } \\
\text { melalui } \\
\text { kebijakannya } \\
\text { - } \\
\text { Sosial, budaya } \\
\text { dan religi }\end{array}$ & $\begin{array}{l}\text { Strategi SO } \\
\text { - Diversifikasi produk dengan konsep tetap } \\
\text { pada produk inti } \\
\text { - } \text { Peningkatan kualitas sumber daya manusia } \\
\text { melalui pendidikan dan pelatihan } \\
\text { - Peningkatan kualitas pendidikan melalui } \\
\text { penggunaan teknologi yang terapan } \\
\text { - } \text { Bauran pemasaran dan personal traits } \\
\text { yang mendukung diversifikasi }\end{array}$ & $\begin{array}{l}\text { Strategi WO } \\
\text { Peningkatan } \\
\text { penerimaan } \\
\text { melalui upaya } \\
\text { menambah } \\
\text { sumbernya, } \\
\text { karena aktiva } \\
\text { sangat } \\
\text { mendukung } \\
\text { Efisiensi } \\
\text { operasional } \\
\text { menjadi } \\
\text { perhatian }\end{array}$ \\
\hline $\begin{array}{l}\text { Treaths }(\mathrm{T}) \\
- \text { Hubungan } \\
\text { dengan sumber } \\
\text { input dan } \\
\text { penyerap } \\
\text { output } \\
- \text { Kesempatan }\end{array}$ & $\begin{array}{l}\text { Strategi ST } \\
\text { - } \quad \text { Kualitas output menjadi perhatian, } \\
\text { khususnya ilmu terapan, sehingga output } \\
\text { bukan hanya sebagai pencari kerja, tetapi } \\
\text { sebagai pembuat lapangan kerja. } \\
\text { - Strategi dan bentuk pelayanan perlu } \\
\text { memperhatikan pesaing }\end{array}$ & $\begin{array}{ll}\text { Strategi WT } \\
\text { - } \quad \text { Bauran } \\
\text { pemasaran lebih } \\
\text { inovatif, terutama } \\
\text { bauran harga. }\end{array}$ \\
\hline
\end{tabular}


kerja

- Pesaing

(kuantitas dan

kualitas)

Sumber : data primer diolah

Dalam rangka lebih spesiknya strategi level korporasi yang akan ditentukan, maka perlu dilakukan pembentukan grafik SWOT atau dikenal dengan Grand Strategi Selection Matrix. Langkah awal yang dilakukan untuk pembentukannya adalah menentukan matrik SPACE-nya, sebagai berikut :

Tabel 5. Matrik SPACE AMM Tahun 2020.

\begin{tabular}{|c|c|c|c|c|c|}
\hline No. & Faktor Internal & Skor & No. & Faktor Eksternal & Skor \\
\hline A. & Keunggulan & & A. & Peluang & \\
\hline 1. & Kuantitas karyawan & 4 & 1. & Nilai tukar & 2 \\
\hline 2. & Kualitas karyawan & 4 & 2. & Inflasi & 2 \\
\hline 3. & Kerajinan karyawan & 4 & 3. & Suku bunga & 3 \\
\hline 4. & Tingkat perputaran karyawan & 4 & 4. & Pertumbuhan ekonomi & 2 \\
\hline 5. & Kecukupan modal kerja & 5 & 5. & Pemerintah & 4 \\
\hline 6. & Likuiditas & 5 & 6. & Sosial & 4 \\
\hline 7. & Solvabilitas & 5 & 7. & Budaya & 4 \\
\hline 8. & Output & 4 & 8. & Religi & 4 \\
\hline 9. & Penggunaan peralatan & 4 & 9. & Nilai produksi NTB & 2 \\
\hline 10. & $\begin{array}{l}\text { Teknologi dalam pelajaran } \\
\text { tertentu }\end{array}$ & 3 & 10. & $\begin{array}{l}\text { Kesiapan pengeluaran } \\
\text { untuk pendidikan }\end{array}$ & 2 \\
\hline 11. & Kelancaran proses belajar & 4 & & & \\
\hline 12. & Program penanganan output & 3 & & & \\
\hline 13. & Peningkatan kualitas produk & 4 & & & \\
\hline 14. & Promosi melalui brosur & 3 & & & \\
\hline 15. & Promosi melalui media elektr. & 3 & & & \\
\hline 16. & Promosi melalui media massa & 3 & & & \\
\hline 17. & Pembayaran SPP & 3 & & & \\
\hline 18. & Pembayaran SKS & 3 & & & \\
\hline 19. & Pembayaran pembangunan & 3 & & & \\
\hline 20. & Bauran distribusi & 4 & & & \\
\hline 21. & Struktur organisasi & 4 & & & \\
\hline 22. & Hubungan dengan yayasan & 5 & & & \\
\hline 23. & $\begin{array}{l}\text { Pencatatan masukan dan } \\
\text { keluaran }\end{array}$ & 4 & & & \\
\hline 24. & Personal traits Ketua & 4 & & & \\
\hline 25. & $\begin{array}{l}\text { Personal traits para Pembantu } \\
\text { Ketua }\end{array}$ & 4 & & & \\
\hline 26. & Personal traits Yayasan & 4 & & & \\
\hline 27. & Good wiil & 2 & & & \\
\hline & Total & 102 & & Total & 29 \\
\hline B. & Kelemahan & & B. & Hambatan & \\
\hline & Aktivitas & 2 & 1 & $\begin{array}{l}\text { Hubungan dengan Sumber } \\
\text { input }\end{array}$ & 4 \\
\hline 2. & Promosi melalui kunjungan & 3 & 2 & Hubungan dengan & 4 \\
\hline
\end{tabular}




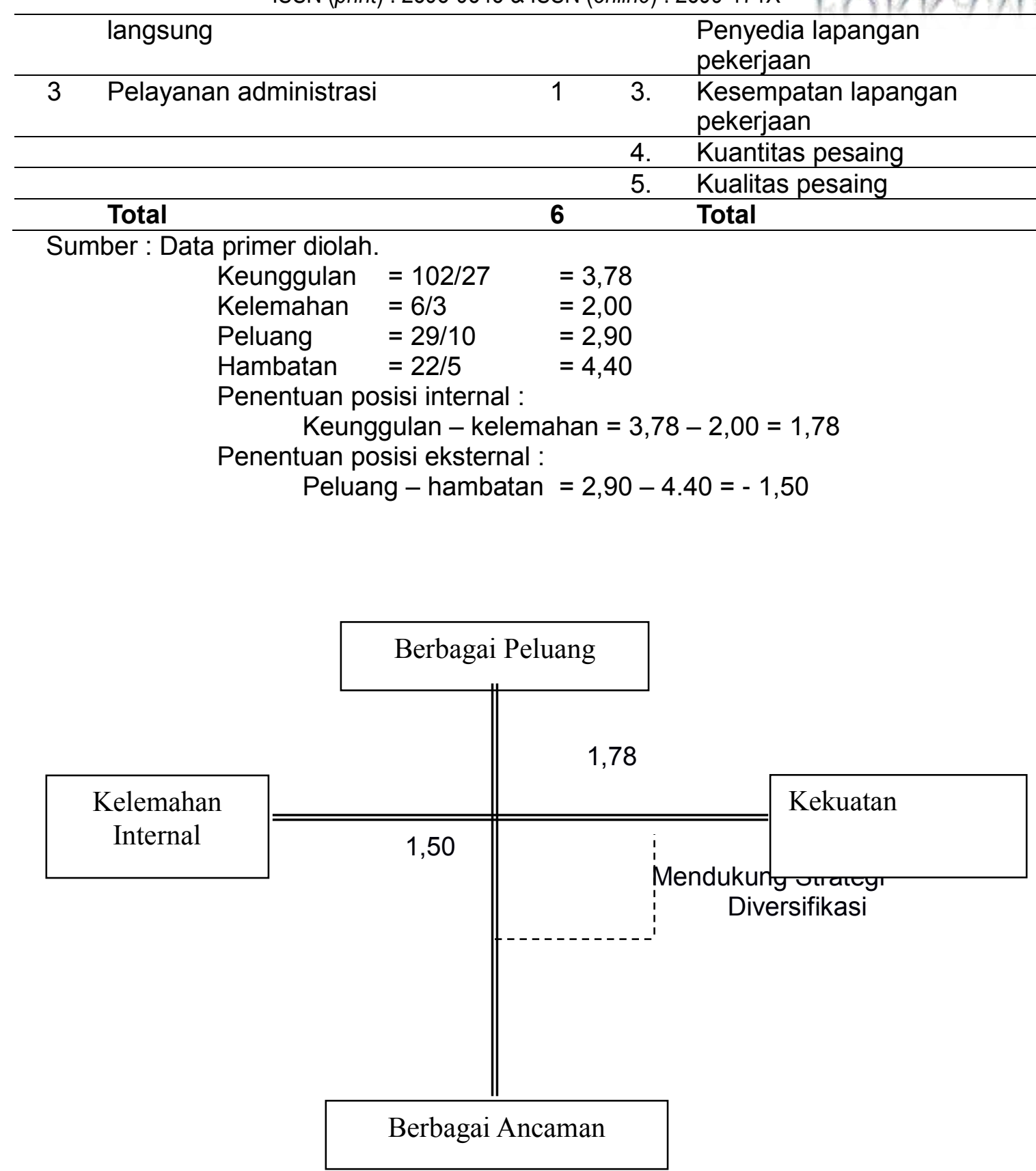

Gambar 1. Grafik SWOT (Grand Strategy) AMM Tahun 2020.

\section{Pembahasan}

STIE AMM dalam menjalankan usahanya berupa pelayanan pendidikan, khususnya yang berhubungan dengan ilmu ekonomi harus menerapkan strategi yang agresif. Dalam hal ini, pihak pengelola harus memanfaatkan keunggulan internal yang dimiliki untuk memanfaatkan peluang yang muncul. Hal penting yang perlu mendapatkan kajian lebih lanjut adalah penerapan strategi yang tepat pada level fungsional. Strategi level fungsional yang diterapkan harus mendukung strategi korporasi berupa strategi diversifikasi.

Strategi bauran produk yang harus dilakukan adalah meningkatkan kualitas pelayanan atau melakukan langkah tertentu sehingga produk pelayanan pendidikan yang dihasilkan berbeda dengan pesaing. Penerapan akrab teknologi yang terkait dengan ilmu 
ekonomi menjadi acuan, seperti akrab aplikasi komputer, pemakaian program berhubungan dengan ilmu ekonomi, bank kecil yang bukan sekedar terkait dengan tempat atau ruangan saja, tetapi menggunakan peralatan yang berhubungan dengan perbankan.

Strategi bauran di atas terkait dengan strategi positioning product, di mana dapat dilakukan oleh STIE AMM dilihat dari aliran kas masuk bersihnya. Hal penting yang juga dapat dilakukan oleh pengelola STIE AMM terkait dengan upaya memposisikan pelayanannya berbeda dengan pelayanan pendidikan lainnya adalah membuat bidang usaha sebagai tempat belajar siswa secara praktik. STIE AMM dapat memiliki lembaga keuangan (perkreditan) dan bisnis lainnya yang dapat memberikan daya tarik pada pasar potensial dan sekaligus sebagai tempat belajar mahasiswa, Apabila usaha yang dimiliki di pasar aktual mengalami perkembangan akan memberikan emosi positif bagi pasar potensial (Cravens \& Piercy, 2006)

Hal di atas bukan merupakan strategi sebatas pola pikir, karena pada dasarnya STIE AMM dapat mengaktualisasikannya. Hal penting adalah penggunaan sumber daya yang ada dengan pola pikir memberikan keuntungan yang berimbang. Strategi di atas merupakan upaya untuk menghasilkan produk pelayanan pendidikan yang ditawarkan berbeda dengan produk yang ditawarkan oleh pesaing. Hal ini harus menjadi orientasi dan dilakukan evaluasi secara periodik, karena pesaing juga melakukan strategi untuk meningkatkan daya saingnya.

Strategi lain yang berhubungan dengan diversifikasi produk tidak hanya bersifat menghasilkan produk yang berbeda. Strategi yang dapat diterapkan adalah melakukan modifikasi atau inovasi atas produk utama yang ada. STIE AMM dengan produk utama berupa pendidikan strata satu dan diploma untuk ilmu ekonomi (manajemen dan akuntansi) dapat melakukan penambahan program studi yang masih berkaitan dengan program studi yang sudah ada. Produk yang dapat ditawarkan berupa pelayanan pendidikan akuntansi syariah, manajemen rumah sakit, perpajakan atau sejenisnya (David \& Moorman, 2017)

Berbagai alternatif strategi di atas untuk strategi yang berhubungan dengan bauran produk. Strategi tersebut harus didukung dengan strategi lain yang terdapat dalam bauran pemasaran lainnya. Bauran harga yang diterapkan harus mendukung strategi yang telah ditetapkan pada strategi bauran produk untuk mewujudkan strategi diversifikasi.

Strategi yang ditetapkan untuk bauran harga adalah penetration pricing, hal ini dengan pertimbangan bahwa pelayanan pendidikan berbeda dengan produk lainnya. Pelayanan pendidikan yang ditawarkan pada masyarakat harus dijalankan dengan konsep pemasaran sosial. Kesejahteraan pasar potensial harus diperhatikan pada saat menjadi konsumen efektif ataupun pada periode pasca-nya. Harga yang ditetapkan oleh STIE AMM selama ini yang berhubungan dengan harga dasar dapat ditetapkan. Hal penting yang perlu diupayakan adalah masalah pembayaran yang lebih rendah untuk mahasiswa yang mempunyai prestasi yang tinggi dan perlu juga diterapkan waktu pembayaran guna meringankan pengorbanan konsumen. Secara teoritis, penerapan harga ini berhubungan dengan discount dan sistem kredit dalam pembayaran.

Bauran harga yang diterapkan harus mendukung peningkatan penerimaan jumlah mahasiswa. Perolehan nilai lebih dari kas masuk terhadap kas keluar hendaknya dicapai melalui peningkatan jumlah mahasiswa yang diterima, bukan akibat peningkatan harga jual pelayanan.

Dalam rangka mendukung strategi bauran produk dan bauran harga guna mewujudkan strategi level korporasi, maka perlu diterapkan strategi yang tepat pula untuk bauran promosi. Bauran promosi yang harus diterapkan harus menjangkau wilayah yang luas dan bersifat menarik. Hal penting yang juga perlu diterapkan adalah promosi yang dilakukan harus membentuk image konsumen potensial. Untuk itu, perlu juga dilakukan kegiatan promosi yang bersifat periodik dan bukan hanya pada waktu mendekati kelulusan siswa SMA atau sederajat. Hal ini sangat perlu dilakukan, karena produk berupa layanan pendidikan bukan good shopping atau sejenisnya yang dapat dipilih 
dengan keputusan yang insidental. Konsumen untuk produk pendidikan akan mengambil keputusan menggunakan alternatif pelayanan pendidikan tertentu setelah dilakukan tahap-tahap yang panjang dalam proses pembelian. Hal tersebut menyangkut pengorbanan yang tinggi, waktu penggunaan pelayanan yang panjang dan menentukan masa depan yang bersangkutan (Muhammad, 2004)

Bentuk bauran pemasaran lain yang mendukung berbagai bauran di atas adalah bauran distribusi. Bauran distribusi yang diterapkan adalah menciptakan produk yang dihasilkan sedekat mungkin dengan konsumen. Hal ini tidak dapat dilakukan dalam bisnis pelayanan pendidikan, karena konsumen (mahasiswa) yang harus mendatangi STIE AMM.

Adanya keterbatasan tersebut, maka hal yang diupayakan adalah memiliki tempat yang strategis. Terkait dengan hal ini, telah dikakukan dengan baik oleh STIE AMM. Kampus satu (1) yang dimiliki berada di pusat Kota Mataram, sedangkan kampus dua (2) sejalan dengan perkembangan yang ada akan menjadi tempat yang strategis pula (masih berada di dalam Kota Mataram).

Bauran lain yang perlu ditetapkan dengan baik dalam bisnis pelayanan pendidikan adalah personal traits. Personal traits merupakan ciri kepribadian karyawan yang dimiliki, terutama pihak-pihak yang mempunyai andil cukup besar dalam lembaga STIE AMM. Melalui perpaduan berbagai strategi bauran pemasaran dan personal traits di atas, maka akan dapat mendukung strategi diversifikasi yang dijalankan oleh STIE AMM dan pada sisi lain dapat mengatasi permasalahan penurunan jumlah mahasiswa pada periode terakhir ini. Strategi yang ditetapkan baik pada level korporat ataupun level fungsional harus dibentuk berdasarkan analisis dan pertimbangan yang mendalam, sehingga menghasilkan peningkatan aliran kas masuk melalui menerimaan mahasiswa yang meningkat, sehingga STIE AMM dapat tumbuh menjadi pelayanan pendidikan yang tampil dalam persaingan yang kompetitif.

\section{E. KESIMPULAN}

Strategi level korporasi yang diterapkan oleh STIE AMM berdasarkan analisis yang telah dilakukan adalah strategi diversifikasi. Strategi level fungsional merupakan bauran pemasaran dan personal Traits yang di kembangkan untuk mendukung strategi diversifikasi. Strategi level fungsional berupa : strategi positioning product, diversifikasi produk, strategi penetration pricing, promosi yang dapat membentuk image konsumen potensial dan bersifat periodik, produk pelayanan pendidikan sedekat mungkin dengan konsumen, dan Personal traits dalam pengambilan keputusan dilakukan dalam upaya mendukung strategi di level korporasi.

Strategi level korporasi yang diterapkan oleh STIE AMM berdasarkan analisis yang telah dilakukan adalah strategi diversifikasi. Strategi level fungsional merupakan bauran pemasaran dan personal Traits yang di kembangkan untuk mendukung strategi diversifikasi. Strategi level fungsional berupa : strategi positioning product, diversifikasi produk, strategi penetration pricing, promosi yang dapat membentuk image konsumen potensial dan bersifat periodik, produk pelayanan pendidikan sedekat mungkin dengan konsumen, dan Personal traits dalam pengambilan keputusan dilakukan dalam upaya mendukung strategi di level korporasi. 


\section{DAFTAR PUSTAKA}

Alma, B. (2018). Manajemen Pemasaran dan Pemasaran jasa (13th ed.). CV. Alfabeta.

Cooper, D. R., \& Emory, W. (1996). Metode penelitian bisnis (E. Gunawan (ed.); 5th ed.). Erlangga.

Cravens, D. W., \& Piercy, N. F. (2006). Strategic Marketing (8th ed.). McGraw-Hill.

David, A., \& Moorman, C. (2017). Strategic Market Management (11th ed.). Wiley.

Kotler, P. (2012). Manajemen pemasaran: analisis, perencanaan, implementasi dan pengendalian (A. A. Hermawan (ed.)). Erlangga.

Kotler, P., \& Armstrong, G. (2012). Prinsip-Prinsip Pemasaran (A. Kusumawati (ed.); 13th ed.). Erlangga.

Lesmana, R., Sutarman, A., \& Sunardi, N. Building A Customer Loyalty Through Service Quality Mediated by Customer Satisfaction. American Journal of Humanities and Social Sciences Research (AJHSSR), 5(3), 38-45

Lesmana, R., Sunardi, N., Hastono, H., \& Widodo, A. S. (2021). Perceived Quality Membentuk Customer Loyalty via Brand Equity pada Pengguna Smartphone Merek Xiaomi di Tangerang Selatan. Jurnal Pemasaran Kompetitif, 4(2), 157-167

Lesmana, R., Sunardi, N., \& Kartono. The Effect of Financing and Online Marketing on MSMEs Income Increasing at Intermoda Modern Market BSD City Tangerang Selatan. American Journal of Humanities and Social Sciences Research (AJHSSR), 5(7), 25-34

Manurung, M. T., Sugiarto, J., \& Munas, B. (2016). Membangun Keunggulan Bersaing Untuk Meningkatkan Kinerja Bisnis Pada Industri Kecil Menegah Tenung Ikat Di Troso, Jepara. Jurnal Bisnis Strategi, 25(2), 171-182. https://doi.org/10.14710/jbs.25.2.171-182

Muhammad, S. (2004). Manajemen Strategik: Konsep dan Kasus (3rd ed.). UPP-AMP YKPN.

Rangkuti, F. (2014). ANALISIS SWOT: Teknik Membedah Kasus Bisnis. Gramedia Pustaka Utama.

Risdwiyanto, A., \& Dharmmesta, B. S. (2001). Pengembangan Konsep Jasa Pendidikan Tinggi Berbasis Keinginan Konsumen Potensial. Journal of Indonesian Economy and Business, 16(4), 401-420.

Sunardi, N., \& Lesmana, R. (2020). Konsep Icepower (Wiramadu) sebagai Solusi Wirausaha menuju Desa Sejahtra Mandiri (DMS) pada Masa Pandemi Covid19. JIMF (Jurnal IImiah Manajemen Forkamma), 4(1).

Sunardi, N., Nurzaman, E., Sarwani., Lesmana, R., Hasbiayah, W.(2021). Peran Digital Marketing Dan Manajemen Keuangan dalam Upaya Peningkatan Pendapatan UMKM yang Berdampak Pada Kesejahteraan Masyarakat di Tengah Pandemi Covid 19, Denpasar. 2(2). 96-104

Tjiptono, F. (2008). Strategi Pemasaran (3rd ed.). Andi Offset.

Tjiptono, F., \& Chandra, G. (2011). Service, Quality \& Satisfaction (3rd ed.). Andi Offset.

Tjiptono, F., \& Chandra, G. (2012). Pemasaran Strategik (2nd ed.). Andi Offset. 